\title{
Scale-dependent associations of predators and prey: constraints imposed by flightlessness of common murres
}

\author{
Gail K. Davoren $^{1, *}$, William A. Montevecchi ${ }^{1}$, John T. Anderson ${ }^{2}$ \\ ${ }^{1}$ Biopsychology Programme, Departments of Biology and Psychology, Memorial University of Newfoundland, St. John's, \\ Newfoundland A1B 3X9, Canada \\ ${ }^{2}$ Department of Fisheries and Oceans, Science Branch, PO Box 5667, St. John's, Newfoundland A1C 5X1, Canada
}

\begin{abstract}
We examined the behavioural interactions of a mobile marine predator, the common murre Uria aalge, and its prey in a cold ocean regime in the context of shifting foraging constraints of the predator during various periods of the year. To do this, we explored the scale-dependent distribution patterns of murres in relation to their prey under 2 mobility regimes: (1) during the pre-breeding period when murres can fly and (2) during the post-breeding or moulting period when murres are flightless and are accompanied by flightless juveniles. In addition, we documented for the first time the relative contributions of different prey types in the diets of murres during moult using stable isotopic analysis. Flightless adult and juvenile murres were concentrated on a meso-scale $(>100 \mathrm{~km})$ in an area (nursery area) where significantly greater amounts of non-capelin, mainly crustaceans, were located in closely spaced aggregations. Accordingly, flightless murres had variable proportions of fish (capelin Mallotus villosus) and crustaceans in their diet, whereas breeding murres exclusively ate capelin. At fine- and coarse-scales $(0.1$ to $100 \mathrm{~km})$, murres that could fly during pre-breeding tracked prey at smaller spatial scales (3 to $4 \mathrm{~km}$ ) than flightless murres (6 to $9 \mathrm{~km}$ ). We hypothesize that varying mobility regimes and energetic demands (activity levels) of murres during these 2 periods resulted in divergent perceptions of the foraging environment and subsequently in varying tracking scales of prey. This has important implications for the scale of study during different periods of the annual cycle of a predator, when varying constraints and trophic levels may interact to produce diverse behavioural responses to prey distribution and densities.
\end{abstract}

KEY WORDS: Scale-dependence $\cdot$ Tracking scale $\cdot$ Predator-prey $\cdot$ Stable isotope analysis $\cdot$ Common murre $\cdot$ Uria aalge $\cdot$ Capelin $\cdot$ Mallotus villosus

Resale or republication not permitted without written consent of the publisher

\section{INTRODUCTION}

A focal theme in ecology is the delineation of predator responses to prey (Sih 1984). Predator-prey theory focuses on the effects of prey density and diversity on the behaviour and demographics of predators (e.g. Solomon 1949, Holling 1966). Responses of predators to prey density can be categorized as (1) numerical, through survival and reproduction, (2) behavioural,

\footnotetext{
*Email: z73gkd@mun.ca
}

through individual-level consumption rates (functional response) and (3) distributional, through movement patterns (aggregative response; Hassell 1966, Holling 1966). The spatial overlap of high predator-density areas with high prey-density areas depends on the spatial and temporal scales at which predators search for and subsequently track their prey (Schneider \& Piatt 1986). Tracking scales of mobile predators to prey are highly variable, and characteristic scales of association are rarely identified (Schneider \& Piatt 1986). The study of tracking scales of predators and prey simultaneously integrates individual-level foraging be- 
haviour and population-level foraging-habitat selection (Fretwell \& Lucas 1970).

Seabirds are the most mobile marine predators. They can disperse and aggregate at greater speeds than their mobile prey and, thus, respond quickly to spatial variations in their prey (Russell et al. 1992). Many factors likely influence how seabirds perceive the heterogeneity in prey density within their environment (Grunbaum 1998) and, subsequently, contribute to the range of tracking scales observed for seabirds (see Schneider 1991, Haney \& Solow 1992, Russell et al. 1992 for reviews). The physiological requirements for survival, or time to starvation (Horne \& Schneider 1994), is likely the most important determinant of the tracking scale of seabirds due to their high metabolic rates and low energy reserves compared to other marine animals (Gabrielsen 1994, Gaston \& Jones 1998). Physical characteristics of the foraging environment of seabirds, such as hydrographic regimes, combined with prey behaviour, influence the spatial scale and density of prey patchiness (Mehlum et al. 1996, Ostrand et al. 1998) and the stability of prey patches in space and time (Cairns \& Schneider 1990, Hunt \& Harrison 1990, Coyle et al. 1992, Decker \& Hunt 1996, Irons 1998). These factors in turn affect predator tracking scales (Rose \& Leggett 1990, Davoren 2000). Changes in biological characteristics of the foraging environment, such as the proportion of available prey types, can cause shifts in prey preferences that also influence spatial interactions between predators and prey and result in unpredictable predator-prey interactions (e.g. Regehr \& Montevecchi 1997). Overall, the physiological requirements of seabirds and the bio-physical characteristics of their foraging environment change through an annual cycle and result in multi-scale, dynamic foraging strategies and, thus, variable tracking scales for seabird species (Russell et al. 1992).

Common murres Uria aalge (hereafter referred to simply as murres) are pursuit-diving seabirds that typically dive to 20 to $50 \mathrm{~m}$ but can reach depths of 180 to 210 m (Piatt \& Nettleship 1985, Croll et al. 1992). In Newfoundland, murres generally feed on small forage fish, primarily capelin Mallotus villosus (Davoren \& Montevecchi 2003). Dietary analysis, however, has been limited to when seabirds are accessible at colonies (Burger \& Piatt 1990), collected in fishing gear (Piatt 1987, Davoren 2001) or collected during the winter hunting season (Elliot et al. 1990, Rowe et al. 2000). Murres return to colonies during May to secure nest sites and to copulate with mates (Walsh 2001). At this point, adults return to the colony daily and, thus, have a limited foraging range around the colony (i.e. central-place foragers; Orians \& Pearson 1979). One egg is laid during early June and incubated for $1 \mathrm{mo}$, after which the chick is reared at the colony for $3 \mathrm{wk}$. Chicks leave the colony during early August at about $25 \%$ of adult body size and are unable to fly (Gaston \& Nettleship 1981). The male parent accompanies the chick upon colony departure and feeds the flightless juvenile at sea for 1 to 2 mo (Varoujean et al. 1979, Hope Jones \& Rees 1985), at which point they are no longer limited to forage in proximity to colonies. During this period, male and female adults simultaneously shed their flight feathers (Thompson et al. 1998) and are unable to fly (Birkhead \& Taylor 1977).

Capelin, the dominant forage fish in the NW Atlantic, is a major prey for piscivorous fish, birds and mammals (Carscadden et al. 2002). Capelin overwinter in offshore feeding areas near the shelf edge off Newfoundland. They undergo extensive migrations inshore during March to April in order to spawn, primarily on coastal beaches (Carscadden et al. 1989). Capelin first arrive inshore near SE Newfoundland during May (Carscadden et al. 1997), after which they migrate north along the east coast during June and spawn on or near beaches during July (Nakashima 1992). After spawning, the abundance of adult capelin in the study area declines relative to the pre-spawning period (Davoren 2001) due to high mortality of adults during spawning (Vilhjalmsson 1994). During August and September, survivors join immature fish and form large aggregations offshore from NE Newfoundland to southern Labrador, after which they move back to over-wintering sites on the shelf edge (Carscadden \& Nakashima 1997).

In this paper, we examine the scale-dependent patterns of common murre distribution in relation to their prey during different periods of the annual cycle. We focus on 2 periods: (1) pre-breeding, when murres can fly, and (2) post-breeding, when murres are flightless and are accompanied by flightless juveniles. Owing to reduced dispersal capabilities, we predict that at the scale of daily movement patterns (fine- and coarse-

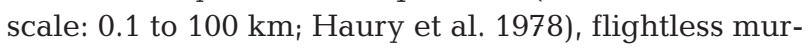
res will be less efficient at tracking prey and, thus, will track prey at larger spatial scales than pre-breeding murres that can fly. At the larger scale of the pre- and post-breeding migration periods (meso-scale: $100 \mathrm{~s} \mathrm{km;}$ Haury et al. 1978), we also predict that flightless adult and juvenile murres will aggregate in areas of high prey density to increase the probability and rate of encounters with prey. Given that the proportion of prey types available influences foraging strategies of predators (e.g. Monaghan et al. 1994), we compare diets of adult murres during breeding, when capelin are abundant and spawning around murre colonies, to post-breeding, when capelin are less abundant due to high spawning mortality. To do this, we use stable isotopic analysis of murre flight feathers to represent the relative contribution of different trophic-level prey in 
murre diets during moulting, and broadly compare this to adult diets during breeding, determined through traditional stomach-/gizzard-content analyses. Results are discussed in the context of foraging constraints imposed by differential mobility regimes, physiological requirements and abundance of prey types during the pre- and post-breeding periods.

\section{MATERIALS AND METHODS}

Study area. This study was conducted on the eastern Newfoundland and Labrador Shelf, where 13 colonies of common murres occur (Fig. 1). Six colonies have $>1000$ breeding pairs: Cape St. Mary's (>10000), Witless Bay Islands (100000), Baccalieu Island (4000), South Cabot Island (2600), Funk Island (340000 to $400000)$ and the Gannet Islands (50 000; Cairns et al. 1989, Canadian Wildlife Service unpubl. data; Fig. 1). Thick-billed murres Uria lomvia also breed on these islands but common murres represent $99 \%$ of the breeding murres, $75 \%$ of which occur at Funk Island (Cairns et al. 1989). Thus, all murres observed at sea were assumed to be common murres unless reliably identified otherwise.

Survey design. The distribution and density of marine birds was quantified in 1999 as part of 2 research programmes on the distribution and abundance of (1) pre-spawning capelin in spring (May) and (2) pelagic juvenile fish in the late summer (August to September). Surveys were conducted aboard the $60 \mathrm{~m}$ Canadian Coast Guard RV 'Teleost'. In May, the area occupied by capelin during over-wintering and inshore migration was covered. Five east-west, $1 \mathrm{NE}-\mathrm{SW}$ and 3 irregularinshore survey lines were conducted from 13 to 28 May 1999, generally at $55 \mathrm{~km}$ north-south spacing. The August-September survey covered a larger area in order to document the distribution of pelagic juvenile fish. Fifteen east-west, 1 north-south and 6 inshore-irregular survey lines were conducted from 23 August to 16 September 1999. This survey began at $49^{\circ} \mathrm{N}$ and progressed north (23 August to 7 September), then returned to $48^{\circ} 30^{\prime} \mathrm{N}$ and progressed south (September 8 to 16). Statistical significance for comparisons in this study was set at $p=0.05$ and all means are reported as $\pm 1 \mathrm{SE}$ unless otherwise indicated.

Acoustic estimates. The distribution and abundance of nekton in the water column were estimated based on acoustic backscattering strength using a Simrad EK500 echo-sounding system calibrated with a tungsten carbide standard target. This echosounder operated through a hull-mounted $38 \mathrm{kHz}$ split-beam transducer. The transducer was at a depth of $6 \mathrm{~m}$ and acoustic signals were not reliable until $15 \mathrm{~m}$ deep. Vessel speed was maintained between 8 and 10 knots.

Raw high-resolution acoustic data (volume backscattering strengths, $S_{\mathrm{v}}$ ) were recorded continuously throughout both surveys. Data acquisition parameters were: pulse length $=1 \mathrm{~ms}$, bandwidth $=3.8 \mathrm{kHz}$, ping rate $=1.5 \mathrm{~s}, 2$-way beam angle $=-20.6 \mathrm{~dB}$, and collection $s_{\mathrm{v}}$ threshold $=-85 \mathrm{~dB}\left(\mathrm{O}^{\prime}\right.$ Driscoll et al. 2001). Prior to integration, an $S_{\mathrm{v}}$ threshold $(-80 \mathrm{~dB})$ was applied, allowing the detection of a single small capelin $(<100 \mathrm{~mm})$ but filtering out other biological and nonbiological 'noise' (R. O'Driscoll pers. comm.). Capelin schools were visually identified in acoustic files by experienced capelin acoustic biologists (May 1999: F. Mowbray; August-September 1999: R. O'Driscoll). Visual discriminations were groundtruthed using biological samples caught in both a midwater trawl (International Young Gadoids Pelagic Trawl) and a bottom trawl (Campelen Trawl, see Davoren 2001). After integration, the average back-

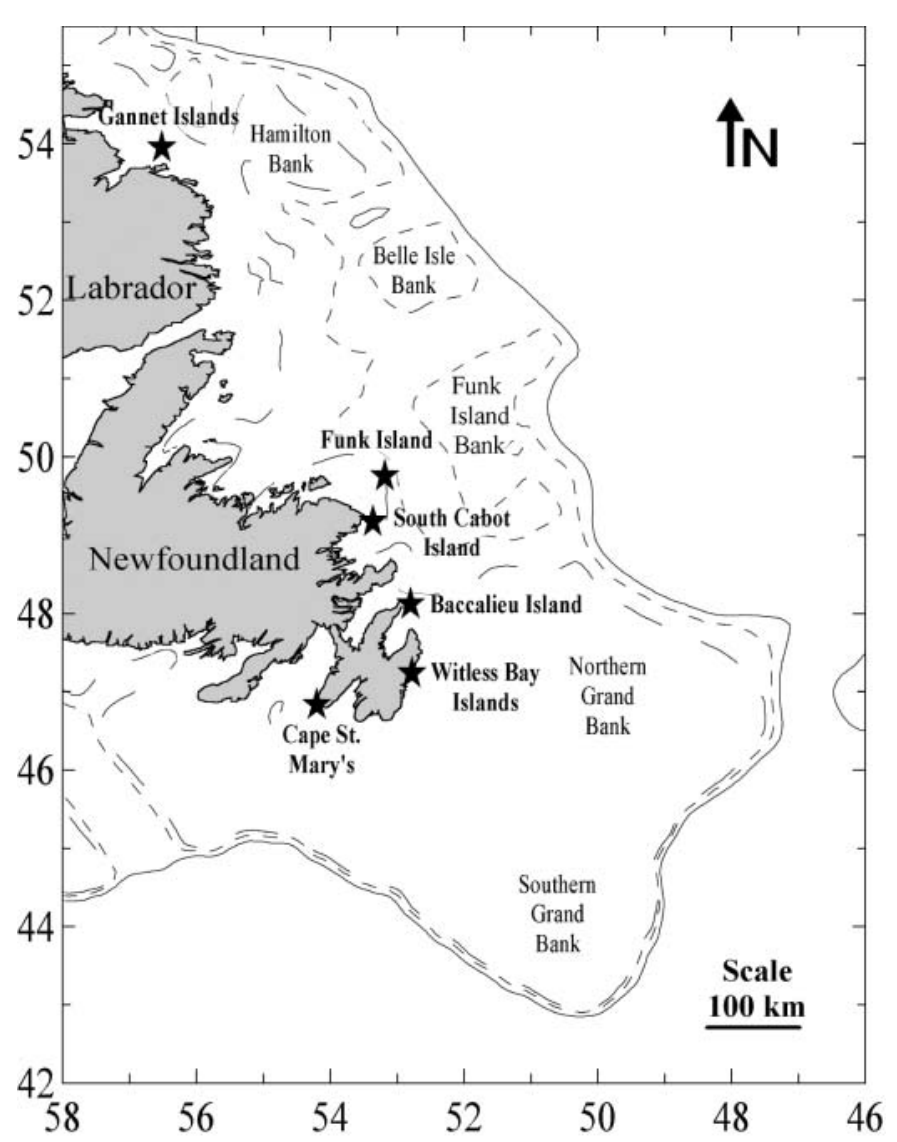

Fig. 1. Map of the study area showing the 6 main breeding colonies $(\star)$ of common murres Uria aalge in the NW Atlantic. Depth contours are $200 \mathrm{~m}(--), 300 \mathrm{~m}(----)$ and $500 \mathrm{~m} \mathrm{(-)}$ 
scatter area for acoustic targets over the whole water column (15 to $500 \mathrm{~m}$ ) was converted to average area of scattering ( $s_{\mathrm{a}}$ i MacLennan et al. 2002). The $s_{\mathrm{a}}$ due to 'capelin' was subtracted from 'total' to determine 'noncapelin'. We did not convert $s_{\mathrm{a}}$ into prey density because the target strengths of non-capelin were unknown. We acknowledge that some targets may have been outside the size ranges typically consumed by murres (30 to $200 \mathrm{~mm}$; Davoren 2001). Acoustic data are presented as the average $s_{\text {a }}$ per distance category.

Seabird counts. Seabird densities were estimated using standardized strip-transect methods (Method I b, Tasker et al. 1984) during daylight hours (08:30 to 23:30 h Greenwich Mean Time, GMT). One trained and dedicated observer made continuous counts from the bridge ( $20 \mathrm{~m}$ above sea level) using binoculars out to $300 \mathrm{~m}$ in a $90^{\circ}$ arc from the tip of the bow to the port side of the ship. The $300 \mathrm{~m}$ survey width was maintained following Heinemann (1981). Counting was discontinued if visibility was $<300 \mathrm{~m}$ (e.g. fog, high wind speeds). Species names, counts and behavioural descriptions (on water, feeding, flying and flight direction) of birds were entered directly into a laptop computer and counting software (D. Senciall, Birds \& Beasty Counter, 1998, Fisheries and Oceans Canada, Version 1.0) was used to append the GMT, latitude and longitude to each entry. Juvenile murres were identified based on their size and plumage (Hope Jones \& Rees 1985). Juveniles were assigned to 1 of 2 size categories: half and near adult body size. To distinguish moulting and non-moulting adults, each was assigned to 1 of 3 plumage categories, based on the plumage on their head: breeding, transitional and winter (Camphuysen 2002). Bird data are presented as total birds per distance category.

Analysis of scale-dependent distribution patterns. Both surveys consisted of a number of transects where birds and prey were recorded simultaneously and continuously, hereafter referred to as 'segments'. Only adult murres that were assumed to be feeding (diving, sitting on the water) were included in our analyses. Analyses were only performed on segments with $>2$ murres. Forty-seven segments were conducted in May, $36 \%$ of which contained $>2$ murres (segment length: $29.8 \pm 5.0 \mathrm{~km}$, median $=24.7 \mathrm{~km}$, range $=8.1$ to $83.2 \mathrm{~km})$. Sixty-six segments were conducted in August-September, $67 \%$ of which contained $>2$ murres (length: $39.4 \pm 2.4 \mathrm{~km}$, median $=44.5 \mathrm{~km}$, range $=$ 5.7 to $69.7 \mathrm{~km})$.

Univariate neighbour K-statistics were used to assess whether murres, capelin density and non-capelin were distributed significantly different from random within each segment at a number of spatial scales (see O'Driscoll 1998, O'Driscoll et al. 2000). Each segment was partitioned into a series of $100 \mathrm{~m}$ bins, in which murre counts (total number of murres) and prey density $\left(s_{\mathrm{a}} \times 10^{-6} \mathrm{~m}^{2} \mathrm{~m}^{-2}\right)$ were quantified. For each segment, the average number of murres, or average prey density observed (OBS), $E[N(t)] \mathrm{OBS}$, was calculated over all $100 \mathrm{~m}$ bins at different spatial scales $(t)$ (O'Driscoll 1998). The test statistic was calculated following O'Driscoll (1998):

$$
E[N(t)]=N^{-1} \sum_{\substack{i=1 \\ i \neq j}}^{N} \sum_{j=1}^{N} I_{t}\left(u_{i j}\right)
$$

where $N$ is the total number of individuals observed in an area, $u_{i j}$ is the distance from individual $i$ to individual $j$ and $I_{t}\left(u_{i j}\right)$ is an indicator function, that is equal to $I$ if $u_{i j}<t$ but equal to 0 otherwise.

The spatial scales analyzed ranged from $100 \mathrm{~m}$ up to half the length of the segment, increasing at $100 \mathrm{~m}$ increments. Using Monte Carlo procedures, 999 realizations of the data were generated, where each murre or prey-density value was randomly reallocated to a $100 \mathrm{~m}$ bin along the segment. If $E[N(t)]$ OBS was greater than $95 \%$ of the $999 E[N(t)]$, then murre or prey density were significantly clustered. Alternately, if $\mathrm{E}[\mathrm{N}(t)] \mathrm{OBS}$ was equal to or less than the $95 \%$ of the $999 \mathrm{E}[\mathrm{N}(t)]$, then murre or prey density were randomly or uniformly distributed, respectively. This was repeated at all spatial scales for each segment.

We also calculated the average number of murres and average prey density expected from a random (RAND) distribution, E[N(t)]RAND, at each spatial scale for a segment (O'Driscoll 1998). We subtracted $E[N(t)]$ OBS from $E[N(t)]$ RAND to determine $L(t)$, defined as the average number of 'extra' murres or 'extra' prey at each spatial scale. The scale of aggregation of murres and prey was defined by the spatial scale at which $L(t)$ for murres or prey was higher than the succeeding 3 values for a given segment ( $\mathrm{O}^{\prime}$ Driscoll et al. 2000). A measure of the density of murres or prey per aggregation was determined by the value of $L(t)$ at the scale of aggregation ('crowding'). The distance between aggregations of murres and aggregations of prey was defined by the spatial scale at which $L(t)$ reached its maximum for a given segment (O'Driscoll 1998). The mean scale of aggregation, crowding and distance between aggregations of murres and prey for each survey was compared using $t$-tests.

Bivariate K-analysis was used to determine whether there were significantly more murres associated with prey aggregations than would be expected if murres were distributed randomly within a given segment (O'Driscoll 1998). For each segment, $E[N(t)]$ OBS and $E[N(t)]$ RAND at each spatial scale in relation to each prey aggregation in $100 \mathrm{~m}$ increments was calculated using 999 Monte Carlo simulations as above. The $L(t)$ of murres at each spatial scale $(t)$ was again calculated by subtracting $E[N(t)]$ RAND from $E[N(t)]$ OBS. The 
scale of maximum association, or 'tracking scale', of murres to prey was defined by the scale at which $L(t)$ of murres was first higher than the succeeding 3 values. The number of 'extra' murres associated with any given prey aggregation ('crowding') was determined by the value of $L(t)$ for murres at the tracking scale. The mean tracking scale and crowding of murres for each survey was compared using $t$-tests.

Dietary analysis. Primary feathers on the left wing were collected from dead common murres found at the Funk Island colony in August $2000(\mathrm{n}=9)$ and found drowned near fishing gear in July $2000(\mathrm{n}=15)$ near Funk Island. These feathers were grown during the August-September 1999 moult. Owing to reduced mobility during moult, it is likely that these murres would have been within our study area during our survey. Feathers were cleaned using a 2:1 ratio chloroform:methanol solution. Sections of dried feathers from each specimen were removed from the base to include a section of rachis with barbs and were cut into small pieces using sharp scissors to obtain a homogenous feather sample (see Thompson \& Furness 1995). A 0.9 to $1.0 \mathrm{mg}$ subsample was saved for each individual bird. All instruments were cleaned between samples with acetone to avoid cross contamination.

As a proxy for pre-breeding adult diets, the stomach and gizzard contents of murres found drowned near fishing gear in July 2000 were analyzed. The breeding status (presence/absence of brood patch) and sex of each bird was recorded. Intact prey items in the stomach were identified to species and other characteristics (total length, sex, maturity) were recorded where possible. Hard parts (e.g. otoliths) were removed from the digested material in the gizzard and identified to species according to reference collections.

Spent female capelin (total length: $149 \pm 9 \mathrm{~mm}, \mathrm{n}=$ 30) were collected during July 2000 from a bottom trawl (Davoren 2001). These fish would be available to murres during post-breeding dispersal. Fish samples were frozen immediately after capture. A piece of muscle was later removed from each thawed fish and freeze-dried for $48 \mathrm{~h}$. A 2:1 ratio chloroform:methanol solution was used to extract lipids from the muscle tissue. Dried samples were ground into a fine powder and a 0.9 to $1.0 \mathrm{mg}$ subsample was saved from each specimen.

Bird feather and fish muscle samples were mailed to David Harris at the University of California, Davis (Stable Isotope Facility) for determinations of isotope concentrations (see Hobson 1993). We estimated the trophic position of murres using an isotopic fractionation factor of 4.4, according to Mizutani et al. (1992) for fish-eating birds. We used a $\delta^{15} \mathrm{~N}$ of 5.4 for phytoplankton and a nitrogen enrichment factor of 3.8, as determined by Hobson (1993) for our study area. To determine the relative proportion of capelin and crustaceans in the diet of a murre, we followed Hobson (1993), using our measured isotope ratios of carbon and nitrogen for capelin and published isotope ratios for euphausiids in the study area $\left(\delta^{15} \mathrm{~N}\right.$ of euphausiids = 7.9; Hobson \& Montevecchi 1991).

\section{RESULTS}

\section{Murre distribution}

An average of $67 \%$ of the murres observed during each survey were identified to species and $98 \%$ of these were identified as common murres. During May, $36 \%$ of the segments $(n=47)$ contained $>2$ murres and they were mainly found near breeding colonies, although some were also found near the shelf edge (Fig. 2). Flying murres made up $95 \%$ of the total number observed $(\mathrm{n}=1552)$. During August-September, $67 \%$ of the segments $(n=66)$ contained $>2$ murres, indicating that murres were more dispersed over the surveyed area compared to May. Flying murres made up only $5 \%$ of the total number observed $(\mathrm{n}=1401)$ and $86 \%$ of the murres observed were in transitional plumage, both of which signify that the majority of murres were likely undergoing moult. Higher densities of murres were found in the northern part of the study area, while very few murres were found farther south (Fig. 3). Based on these observations, we divided the August-September survey into 2 areas, with the boundary at $52^{\circ} \mathrm{N}$. We refer to the area north of $52^{\circ} \mathrm{N}$ as the 'northern area' and the area to the south of $52^{\circ} \mathrm{N}$ as the 'southern area'.

In the northern area, we counted $85 \%(n=1189)$ of all murre adults during the August-September survey, $95 \%$ of which had transitional plumage and were assumed to be moulting. Segments in the northern area had significantly higher densities of murres (3.1 \pm 1.6 ind. $\mathrm{km}^{-2}, \mathrm{n}=15$ ) compared to the southern area $\left(0.2 \pm 0.1\right.$ ind. $\mathrm{km}^{-2}, \mathrm{n}=29 ; t_{42}=2.49, \mathrm{p}=0.017 ;$ Fig. 3$)$. In contrast, only $13 \%$ of murre juveniles $(n=56)$ were observed in the northern area, all of which were assigned to the near-adult body-size category. In contrast, $83 \%$ of the juveniles observed in the southern area were assigned to the half-adult body-size category. Therefore, juveniles observed in the northern area were large and harder to distinguish from adults than those farther south and, thus, we do not preclude that there were more young-of-the-year in this area that were mistaken as adults.

In the northern area, juveniles were generally accompanied by many adults (1 juvenile with 1 adult: $14 \%$; 1 juvenile with $>1$ adult: $86 \%$ ), whereas the majority of juvenile-adult associations observed far- 

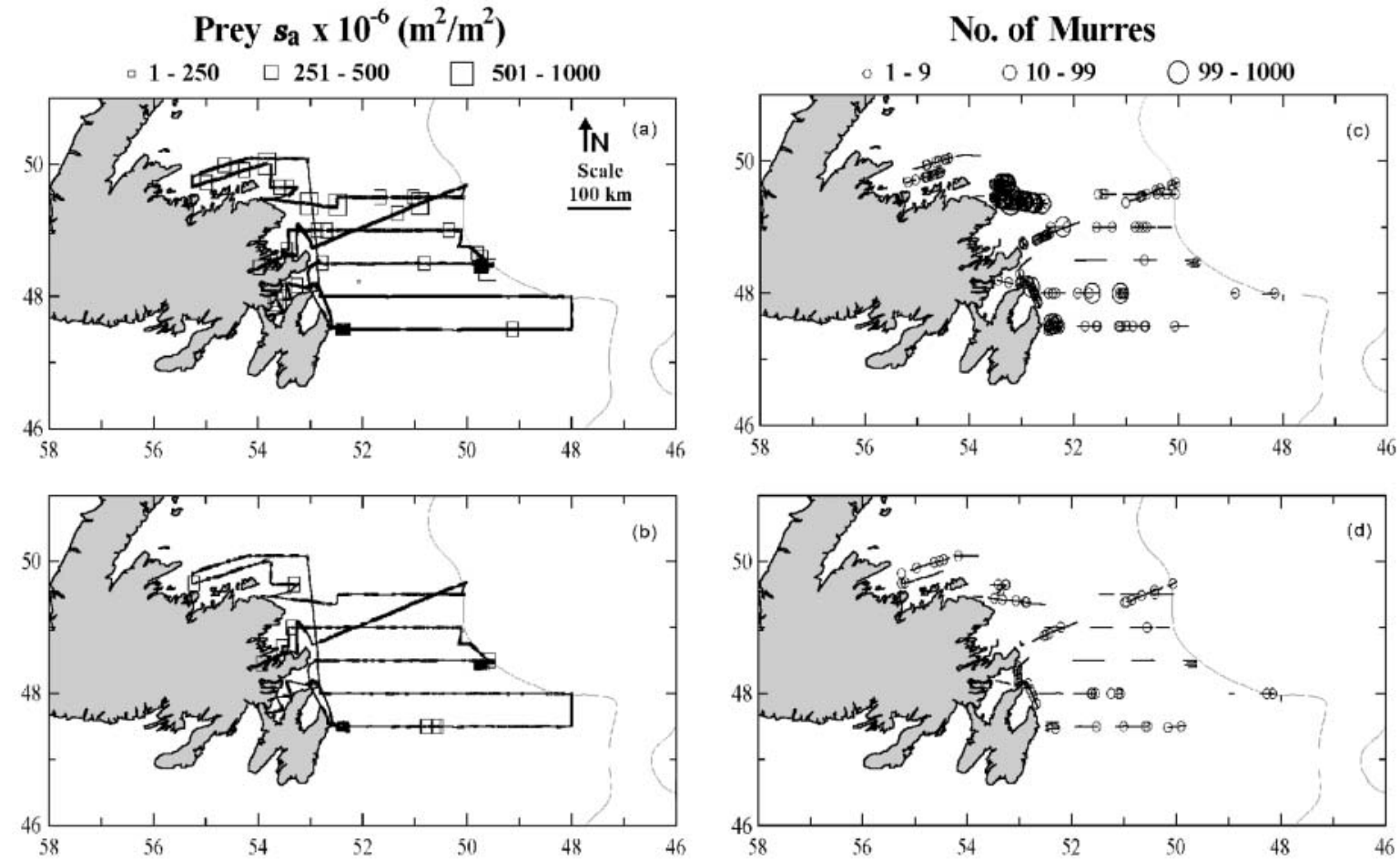

Fig. 2. Distribution of acoustic scatter area $\left(s_{\mathrm{a}} \times 10^{-6}\right)$ of prey due to (a) capelin Mallotus villosus and (b) non-capelin, and the distribution of common murres Uria aalge flying (c) and on the water (d) during the May 1999 survey. Expanding symbols represent the number of murres (circles) or the $s_{\mathrm{a}} \times 10^{-6} \mathrm{~m}^{2} \mathrm{~m}^{-2}$ of prey (squares) per $5 \mathrm{~km}$ block. The $500 \mathrm{~m}$ depth contour is shown $(\stackrel{P}{\longrightarrow}$

Prey $s_{\mathrm{a}} \times 10^{-6}\left(\mathrm{~m}^{2} / \mathrm{m}^{2}\right)$
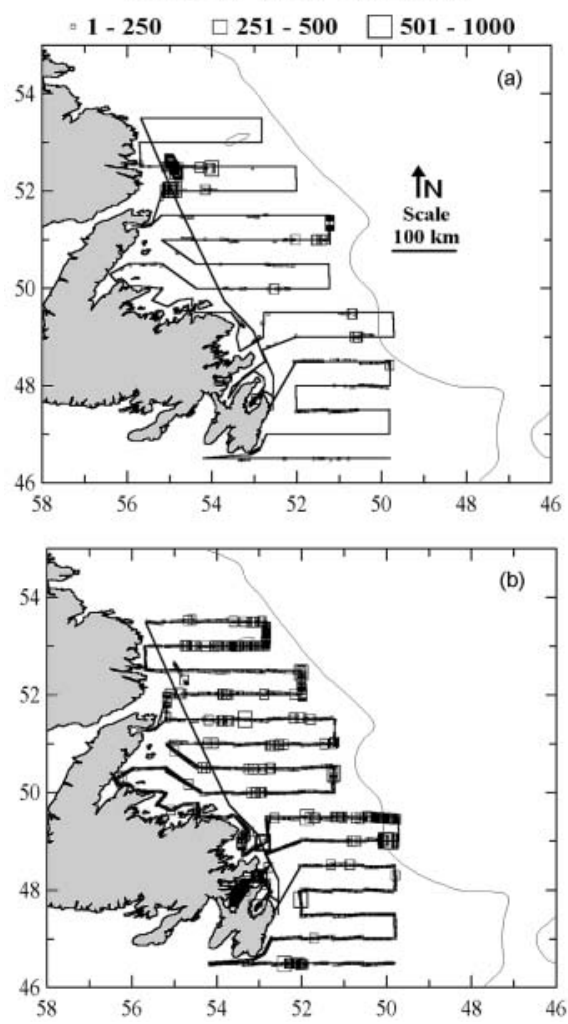

No. of Murres
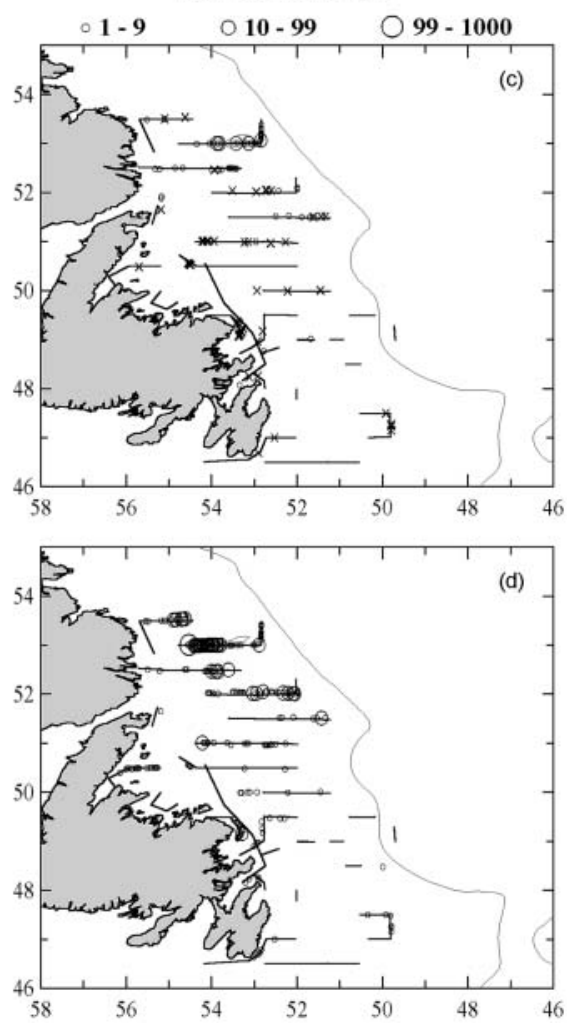

Fig. 3. The distribution of acoustic scatter area $\left(s_{\mathrm{a}} \times 10^{-6}\right)$ of prey due to (a) capelin Mallotus villosus and (b) non-capelin, and the distribution of juvenile common mure Uria aalge $(x)$ and murres flying (c) and on the water (d) during the August-September 1999 survey. Expanding symbols represent the number of murres (circles) or the $s_{\mathrm{a}} \times 10^{-6} \mathrm{~m}^{2} \mathrm{~m}^{-2}$ of prey (squares) per $5 \mathrm{~km}$ block. The $500 \mathrm{~m}$ depth contour is shown (- 
ther south were solitary pairs (1 juvenile with 1 adult: $58 \%$; 1 juvenile with $>1$ adult: $42 \%$ ). When juveniles were observed with more than 1 adult in the southern area, it was obvious which one was the accompanying parent due to their close proximity (within $1 \mathrm{~m}$ of each other), whereas this was not obvious in the northern area. In addition, $91 \%$ of the total murres observed flying $(n=63)$ during the survey were observed in this northern area, while only $9 \%$ were observed farther south (Fig. 3).

Avian predators of juvenile murres (Camphuysen 2002) observed during the August-September survey included both great black-backed gulls Larus marinus $(\mathrm{n}=27)$ and great skuas Catharacta skua $(\mathrm{n}=7)$. These avian predators were concentrated near the 6 main colonies of murres in the southern area, whereas only 1 gull was observed in the northern area.

\section{Prey distribution}

During May, $76 \%$ of the segments that contained $>2$ murres $(n=17)$ also contained capelin. The highest capelin density values $\left(s_{\mathrm{a}} \times 10^{-6} \mathrm{~m}^{2} \mathrm{~m}^{-2}\right)$ were found along the shelf edge and within major bays (Fig. 2). Very few acoustic signals, both capelin and noncapelin, were recorded elsewhere on the shelf. During August-September, $50 \%$ of the segments that contained $>2$ murres $(n=44)$ also contained capelin. The highest capelin density values were found near the northern coast of Newfoundland and southern coast of Labrador and on Funk Island Bank (Fig. 3). Capelin dominated the acoustic scattering area in May com- pared to August-September (Figs. 2 \& 3). Non-capelin acoustic targets in August-September consisted primarily ( $>50 \%$ by mass) of crustaceans (e.g. shrimp, amphipods, euphausiids) with a mix of other fish species (e.g. Atlantic cod Gadus morhua, Arctic cod Boreogadus saida, American sand lance Ammodytes americanus, daubed shanny Lumpenus maculatus; see Davoren 2001).

During the August-September survey, the northern area had significantly higher mean prey density per segment due to non-capelin (north: $5382 \pm 2217 \times$ $10^{-6} \mathrm{~m}^{2} \mathrm{~m}^{-2}$, south: $5.3 \pm 0.1 \times 10^{-6} \mathrm{~m}^{2} \mathrm{~m}^{-2} ; t_{42}=3.41, \mathrm{p}=$ 0.001 ) and capelin, although the latter was not statistically significant (north: $639 \pm 480 \times 10^{-6} \mathrm{~m}^{2} \mathrm{~m}^{-2}$, south: $0.6 \pm 0.02 \times 10^{-6} \mathrm{~m}^{2} \mathrm{~m}^{-2} ; t_{42}=1.87, \mathrm{p}=0.068 ;$ Fig. 3 ) due to the high variability among segments. The main concentration of capelin in this northern area, however, did not show typical vertical migratory behaviour, towards the ocean surface at dusk and back to the seabed at dawn, but rather consistently remained near the seabed (>250 m; O'Driscoll et al. 2001).

\section{Murre-prey interaction}

The aggregation scales of adult murres were significantly larger in May $(3.7 \pm 1.5 \mathrm{~km})$ compared to August-September $(0.4 \pm 0.1 \mathrm{~km})$. Generally, more murres were clustered into smaller aggregations in August-September compared to May (Table 1). The distance between murre aggregations was similar in August-September $(6.3 \pm 1.2 \mathrm{~km})$ and May $(4.0 \pm 1.4 \mathrm{~km}$; Table 1). In May, murres had larger aggregation scales

Table 1. Uria aalge. Summary of distribution patterns and spatial associations of common murres and their prey within segments during pre-breeding (May, $\mathrm{n}=17$ ) and post-breeding (August-September, $\mathrm{n}=44$ ) periods in 1999. Prey were categorized as capelin Mallotus villosus and non-capelin based on acoustic signals $\left(s_{\mathrm{a}} \times 10^{-6} \mathrm{~m}^{2} \mathrm{~m}^{-2}\right)$. Distribution patterns of murres and prey were estimated as aggregation scales $(\mathrm{km})$ and distance between aggregations $(\mathrm{km})$. Densities were estimated as crowding, or the number of murres and amount of prey at the aggregation scale. Spatial associations were estimated as tracking scales (km) of murres to prey and densities were estimated as crowding, or the number of murres at the tracking scale. The percentage of segments with significant clustering of murres and prey and murres associated with prey are indicated in parentheses. Results of $t$-tests comparing these parameters between pre- and post-breeding are given

\begin{tabular}{|c|c|c|c|c|c|c|c|}
\hline & \multicolumn{2}{|c|}{ _ Pre-breeding } & \multicolumn{2}{|c|}{ _ Post-breeding } & \multirow[t]{2}{*}{ df } & \multirow{2}{*}{$\underset{\text { (scale) }}{\mathrm{p}}$} & \multirow{2}{*}{$\begin{array}{c}\mathrm{p} \\
\text { (crowd) }\end{array}$} \\
\hline & Spatial scale $(\mathrm{km})$ & Crowding & Spatial scale $(\mathrm{km})$ & Crowding & & & \\
\hline \multicolumn{8}{|l|}{ Aggregation scales } \\
\hline Murres & $3.7 \pm 1.5(94 \%)$ & $0.9 \pm 0.1$ & $0.4 \pm 0.1(100 \%)$ & $3.9 \pm 1.5$ & 51 & 0.002 & 0.183 \\
\hline Capelin & $2.8 \pm 1.3(100 \%)$ & $1136.2 \pm 504.6$ & $3.1 \pm 0.5(100 \%)$ & $284.9 \pm 117.5$ & 33 & 0.818 & 0.052 \\
\hline Non-capelin & $2.0 \pm 0.6(100 \%)$ & $712.0 \pm 278.3$ & $6.0 \pm 1.2(100 \%)$ & $260.4 \pm 126.5$ & 51 & 0.035 & 0.094 \\
\hline \multicolumn{8}{|c|}{ Distance between aggregations } \\
\hline Murres & $4.0 \pm 1.4$ & & $6.3 \pm 1.2$ & & 50 & 0.280 & \\
\hline Capelin & $6.8 \pm 2.2$ & & $7.6 \pm 1.6$ & & 32 & 0.764 & \\
\hline Non-capelin & $6.7 \pm 2.5$ & & $8.6 \pm 1.3$ & & 49 & 0.459 & \\
\hline \multicolumn{8}{|l|}{ Tracking scales } \\
\hline Murre to capelin & $4.1 \pm 1.2(30 \%)$ & $1.8 \pm 0.5$ & $9.2 \pm 2.8(27 \%)$ & $0.3 \pm 0.2$ & 8 & 0.047 & 0.026 \\
\hline Murre to non-capelin & $3.1 \pm 1.5(30 \%)$ & $0.6 \pm 0.3$ & $6.0 \pm 1.1(22 \%)$ & $1.2 \pm 0.4$ & 11 & 0.038 & 0.263 \\
\hline
\end{tabular}


than capelin and non-capelin, whereas the opposite was true in August-September (Table 1).

The aggregation scales of non-capelin were significantly smaller during May $(2.0 \pm 0.6 \mathrm{~km})$ than AugustSeptember $(6.0 \pm 1.2 \mathrm{~km})$, though density measures within aggregations (crowding) did not differ significantly (Table 1). In contrast, aggregation scales of capelin were similar in May $(2.8 \pm 1.3 \mathrm{~km})$ and AugustSeptember $(3.1 \pm 0.5 \mathrm{~km})$, but density measures within aggregations (crowding) were higher in May compared to August-September (Table 1). Overall, there was a tendency for more prey to occur in smaller aggregations in May compared to August-September (Table 1). The distance between aggregations of capelin did not differ during these 2 surveys, as was true for non-capelin aggregations (Table 1).

The tracking scales of murres to prey within segments were significantly smaller in May relative to August-September for both capelin and non-capelin prey (Table 1). There were higher densities of murres at capelin aggregations (crowding) in May compared to August-September (Table 1). Most segments in both surveys (92 to $100 \%$ ) had aggregation scales at which murres, capelin and non-capelin were significantly clustered. In contrast, approximately one third of all segments showed tracking scales where murres were significantly clustered at prey aggregations (Table 1).

Within the August-September survey, the spatial scale of aggregation for murres, capelin and noncapelin did not differ among the northern and southern areas (Table 2). There were higher densities of murres and capelin at the scales of aggregation (crowding) in the northern area compared to the southern area but non-capelin had similar densities in both areas (Table 2). In the northern area, there were shorter distances between aggregations of non-capelin (5.9 \pm $1.5 \mathrm{~km})$ compared to farther south $(10.3 \pm 1.8 \mathrm{~km}$; Table 2). Only $29 \%$ of the segments where murres were observed in the northern area $(n=14)$ contained acoustic capelin signals. The tracking scale of murres to both capelin and non-capelin, however, did not differ among the areas (Table 2).

\section{Murre diets}

Spent female capelin had $\delta^{15} \mathrm{~N}$ values of $10.2 \pm 1.9 \%$ ( $\mathrm{n}=30$; range: 5.4 to $12.5 \%$ ) and $\delta^{13} \mathrm{C}$ values of $-19.9 \pm$ $0.6 \%$ o ( $\mathrm{n}=30$; range: -18.8 to $-21.1 \%$ ). Murres collected at sea that had drowned near fishing gear $(\mathrm{n}=$ 15) were fresh enough to determine sex and breeding condition: 8 males ( 7 breeders) and 7 females ( 6 breeders). As indicated by stable isotope analysis, murres occupied a range of trophic positions (2.9 to 3.7) during the moulting period and $\delta^{15} \mathrm{~N}$ values were consistent with a variable diet (Table 3 ). The percent of capelin versus crustaceans in the diet varied widely among and within individuals, as shown by the high standard deviations of $\delta^{15} \mathrm{~N}$ compared to $\delta^{13} \mathrm{C}$ (Table 3). Male murres appeared to occupy a higher trophic position than females, shown by their higher $\delta^{15} \mathrm{~N}$ values and lower proportion of crustaceans in their diets (Table 3 ), but this difference was not statistically significant $\left(t_{13}=\right.$ 2.07, $\mathrm{p}=0.059)$. In contrast to the moulting period, all

Table 2. Uria aalge. Summary of distribution patterns and spatial associations of common murres and their prey within segments during post-breeding (August-September) in 1999, divided into the area south of $52^{\circ} \mathrm{N}$ (southern area, $\mathrm{n}=23$ ) and north of $52^{\circ} \mathrm{N}$ (northern area, $\mathrm{n}=14$ ). Prey were categorized as capelin Mallotus villosus and non-capelin based on acoustic data $\left(s_{\mathrm{a}} \times 10^{-6} \mathrm{~m}^{2}\right.$ $\mathrm{m}^{-2}$ ). Distribution patterns of murres and prey were estimated as aggregation scales $(\mathrm{km})$ and distance between aggregations $(\mathrm{km})$. Densities were estimated as crowding, or the number of murres and amount of prey at the aggregation scale. Spatial associations were estimated as tracking scales $(\mathrm{km})$ of murres to prey and densities were estimated as crowding, or the number of murres at the tracking scale. The percentage of segments with significant clustering of murres and prey and murres associated with prey are indicated in parentheses. Results of $t$-tests comparing these parameters between the southern and the northern area are given

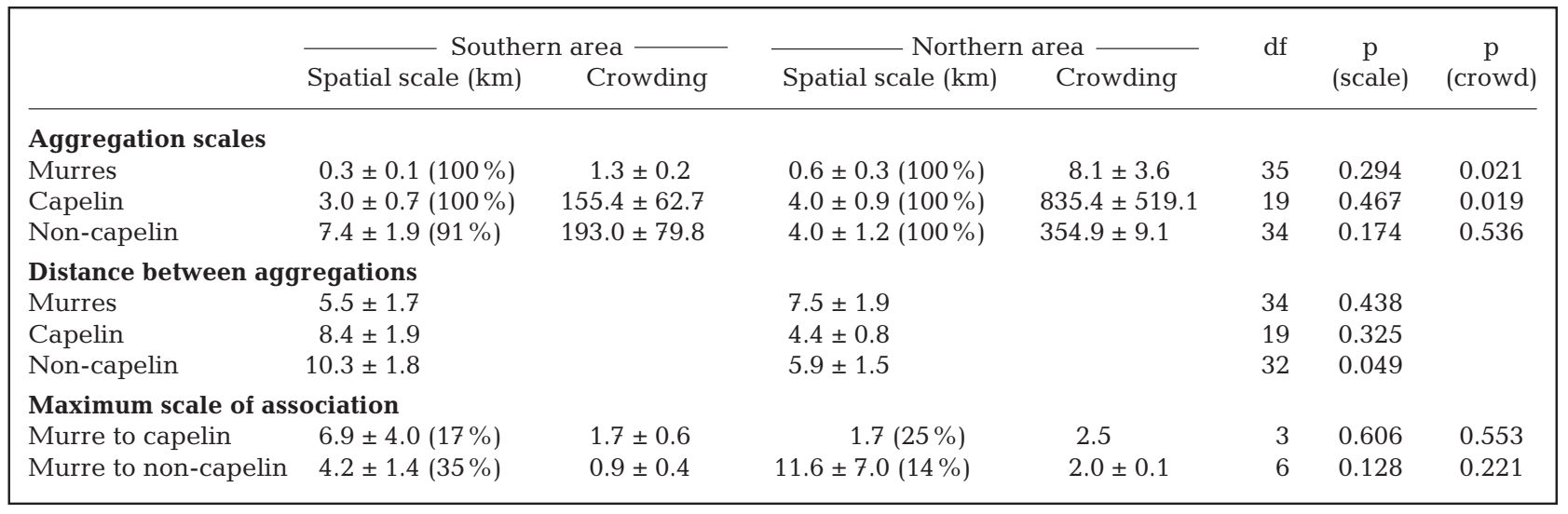


Table 3. Mean percentage of capelin Mallotus villosus in the diet of adult common murres Uria aalge collected in eastern Newfoundland during breeding, through stomach- and gizzard-content analysis (\% by number), and during post-breeding, through stable isotope concentrations of primary feathers (\% relative proportion). Stable nitrogen and carbon isotope concentrations $( \pm \mathrm{SD})$ in primary feathers of common murres and the calculated trophic levels are given, along with the number of individuals sampled (n) and ranges (in parentheses)

\begin{tabular}{|c|c|c|c|c|c|}
\hline Period & $\mathrm{n}$ & $\%$ of capelin & $\delta^{15} \mathrm{~N}(\%)$ & $\delta^{13} \mathrm{C}(\%)$ & Trophic level \\
\hline \multicolumn{6}{|l|}{$\begin{array}{l}\text { Breeding } \\
\text { (July 2000) }\end{array}$} \\
\hline Males and females & 15 & 100 & & & \\
\hline \multicolumn{6}{|c|}{$\begin{array}{l}\text { Post-breeding } \\
\text { ( August-September 1999) }\end{array}$} \\
\hline Males and females & 24 & $77 \pm 20(37-100)$ & $14.8 \pm 0.7(13.4-16.1)$ & $-17.9 \pm 0.3(-18.5$ to -17.3$)$ & $3.3 \pm 0.2(2.9-3.7)$ \\
\hline Males & 8 & $84 \pm 15(39-100)$ & $15.0 \pm 0.5(14.6-16.1)$ & $-17.9 \pm 0.2(-18.1$ to -17.6$)$ & $3.4 \pm 0.1(3.3-3.7)$ \\
\hline Females & 7 & $73 \pm 20(46-99)$ & $14.3 \pm 0.7(13.4-15.3)$ & $-18.0 \pm 0.4(-17.3$ to -18.5$)$ & $3.2 \pm 0.2(2.9-3.4)$ \\
\hline
\end{tabular}

intact prey items and otoliths found in stomachs and gizzards, respectively, of drowned birds collected during breeding were identified as capelin (Table 3). Therefore, murres appeared to exclusively feed on capelin during breeding but had a more variable diet during the post-breeding, moulting period.

\section{DISCUSSION}

Flightless murres were concentrated on a meso-scale in an area where significantly greater amounts of noncapelin, mainly crustaceans (Davoren 2001), were located in closely spaced aggregations. High-density aggregations of capelin were also located in this area but were inaccessible at depth, explaining why murres were generally not found associated with capelin and why diets were more variable and included more crustaceans during the moulting period compared to breeding. The smaller tracking scale of murres to both non-capelin and capelin during pre-breeding relative to post-breeding indicates that constraints associated with flightlessness influenced tracking scales of murres to prey during post-breeding.

\section{Murre diets}

Flightless murres occupied a trophic position similar to those reported in other studies of common murres using stable isotope analysis on a variety of tissues (egg albumen, liver, muscle and bone collagen; Hobson \& Montevecchi 1991, Hobson et al. 1994, Jarman et al. 1996, Sydeman et al. 1997, Thompson et al. 1999). Common murres are generally considered to be piscivorous (Bradstreet \& Brown 1985) but may take a higher proportion of crustaceans during certain times of the year (Ainley et al. 1996, Sydeman et al. 1997). Although direct comparisons of diets derived from tra- ditional and stable isotope analysis should be interpreted with caution due to the under-representation of soft-bodied prey in digested material (Sydeman et al. 1997), moulting murres in this study appeared to eat a lower proportion of capelin than those during breeding. This is consistent with winter diets of adult murres in Newfoundland (Elliot et al. 1990, Rowe et al. 2000). Crustaceans such as euphausiids have a lower caloric content than fish (Spear 1993). Higher encounter rates with these lower quality prey types may explain such a dietary shift, and this shift is also consistent with the higher relative contribution of non-capelin to the overall prey base in the study area during post-breeding compared to pre-breeding (Davoren 2001, this study). Alternately, adult murres may be less selective while moulting due to lower dispersal capabilities or lower activity levels relative to pre-breeding.

\section{Fine-scale associations of murres and prey}

Tracking scales reflect the extent of spatial overlap between aggregations of predators and prey and, therefore, the culmination of energetic costs and benefits realized by predators when establishing adequate encounter rates with prey (Horne \& Schneider 1994). One way predators can maximize encounter rates with prey is to track prey at spatial scales larger than prey aggregations (Horne \& Schneider 1994). Murres appeared to use this strategy during both pre- and post-breeding. At the scale of daily movement patterns, or within segments of our surveys, however, murres that could fly during pre-breeding tracked prey at smaller spatial scales (3 to $4 \mathrm{~km}$ ) than flightless murres (6 to $9 \mathrm{~km}$ ). This can be explained in a number of ways. First, prey aggregations were smaller and contained more prey during pre-breeding compared to post-breeding and, thus, murres could have simply been responding to the distribution and density of 
prey. Second, larger tracking scales of flightless murres could result from the reduced ability of flightless murres to move in response to changing prey density. Reduced dispersal capabilities may lead to perceptual constraints in flightless murres through a reduction in the ability to physically and visually sample (e.g. local enhancement; Wittenberger \& Hunt 1985) their foraging environment to locate prey. Reduced sampling results in a limited knowledge of the locations and qualities of prey aggregations within a restricted range of each individual. Limited mobility and higher costs of switching among aggregations generally lead to unpredictable patterns of spatial association between predators and prey (Abrahams 1989, Tregenza 1995).

It is also possible that the energetic costs of tracking prey at small scales for flightless murres outweighed the benefits gained from higher encounter rates with prey. Therefore the tracking scale may reflect the physiological requirements of flightless murres rather than the distribution and density of prey, as found for Atlantic cod Gadus morhua tracking capelin in Newfoundland (Horne \& Schneider 1994). Flying and egg formation for females during pre-breeding are more energetically demanding activities than swimming and moulting during post-breeding (Murphy \& King 1992, Croll \& McLauren 1993). Therefore murres would require more energy to maintain higher activity levels during pre-breeding compared to post-breeding. In support, moult does not appear to represent an energetic bottleneck for juveniles and adults (Birkhead 1974, but see Holdgate 1971), though very little is known about the energetics of moulting (Adams et al. 2000). We do not conclude, however, that energy expenditure during moult is negligible (Diamond et al. 1993). Higher metabolic rates of waterbirds during moult compared to winter are likely due to both the energy expended in growing new feathers and higher thermogenesis because of the increased exposure to the environment and, thus, increased heat loss (Payne 1972). Murres are not thermally neutral in temperatures less than $15^{\circ} \mathrm{C}$ but generally occupy the ocean at temperatures significantly colder than this (Croll \& McLaren 1993, Davoren 2001). Thermal conductance in water is 2 times higher than in air for swimming birds (de Vries \& van Eerden 1995) and, thus, heat loss is high, due to reduced insulation and increased blood flow to areas of feather growth during moult (Payne 1972).

Predators can also maximize encounter rates with prey by tracking and cueing to the foraging activities of other predators (local enhancement, Grunbaum \& Veit unpubl. data). This strategy involves the diffusion of a network of predators searching for prey within a large aggregation, where predators maintain visual contact and rapidly join others once prey is located (network foraging; Wittenberger \& Hunt 1985). Tracking and aggregation scales of murres and prey during pre-breeding were consistent with a network foragingtype strategy, where murres had larger aggregation scales than their prey but densities of murres were low within aggregations ( 1 murre per $3.7 \mathrm{~km})$. This is also consistent with distribution patterns observed in previous studies on murres and prey (e.g. Schneider \& Piatt 1986, Piatt 1990, Logerwell et al. 1998, Fauchald et al. 2000, Fauchald \& Erikstad 2002). This was not the case, however, during post-breeding, where flightless murres had smaller aggregation scales than their prey and densities of murres within these smaller aggregations were high ( 4 murres per $0.4 \mathrm{~km})$. Flightless murres can rapidly join foraging conspecifics when they are in close proximity and, thus, could reap the benefits of network foraging only on a very fine scale (1 to $1000 \mathrm{~m}$ ). The tight groups formed by flightless murres could instead aid in increased prey consumption rates through cooperative foraging strategies (e.g. herding prey), as observed by Camphuysen \& Webb (1999). Dense, aggregative foraging strategies also occur among many penguin species and were likely used by great auks (Montevecchi \& Kirk 1996).

\section{Meso-scale associations of murres and prey}

The northern area, off southern Labrador, appears to be an important staging and nursery area for flightless murres and juveniles, respectively, breeding in the NW Atlantic. The concentration of birds in this area during the fall was previously documented (Brown 1986, Davoren 2001). Tuck (1961) concluded through recoveries of banded birds that murres from colonies in southern Newfoundland moved north into this area during their post-breeding dispersal. Northward movement against the mean southerly flow of the Labrador Current (Petrie \& Anderson 1983, Colbourne et al. 1997) is probably not energetically expensive because prevailing southwest winds during the fall in the study area likely aid in the transport of surface waters, and the birds on them, toward the northeast (Flint \& Fowler 1998). Our data support the northward movement from colonies off Newfoundland, the most significant of which is Funk Island. First, juveniles observed in this northern nursery area were larger and more difficult to distinguish from adults, indicating that juveniles had been at sea for approximately 1 mo (Varoujean et al. 1979). Common murres at the Gannet Islands off Labrador, farther north of the nursery area, fledge their chicks around late August (Bryant et al. 1999). Therefore, although juveniles from the Gannet Islands could have reached this area by the time we surveyed (September 4 to 7 ), they would have been young, small and easily distinguished from adults. In addition, the majority of murres observed flying were 
in the northern area, suggesting that a few individuals may have already completed moulting (4 to $6 \mathrm{wk}_{\text {; }}$ Birkhead \& Taylor 1977), though it is also possible that these individuals were females that had recently entered the area and had not begun moulting. Female murres usually occupy breeding sites at the colony for $14 \mathrm{~d}$ after the male parent and juvenile have departed (Wanless \& Harris 1986) and are known to fly to nursery/staging areas and then begin the flightless moulting period (Hatch et al. 2000). We do not preclude that some flying birds were pre-moulting females; however, the numbers of flying adults and older juveniles together indicate that some birds ( 5\%) might have finished moulting.

The distribution of murres during pre- and postbreeding periods were similar to the annual migration routes of capelin. Migration routes of capelin have been relatively consistent since surveys began in the 1970s, though during the 1990s, capelin distribution, biology and behaviour have undergone remarkable changes (Carscadden \& Nakashima 1997, Carscadden et al. 2002). These changes included variability in the vertical migration behaviour of capelin (Shackell et al. 1994, O'Driscoll \& Rose 1999), with some of the major concentrations of capelin remaining at depths inaccessible to murres (O'Driscoll et al. 2001). Therefore, even though there was little spatial overlap between flightless murres and capelin, and even though diets of these birds contained high proportions of crustaceans, we do not preclude that capelin may have historically played a more significant role in the post-breeding dispersal patterns of murres in Newfoundland (Tuck 1961, Montevecchi \& Tuck 1987). Alterations in both the behaviour and predictability of these migration routes may have significant consequences on demographic parameters of murres (Rowe et al. 2000, Davoren \& Montevecchi 2003).

Generally, the post-breeding migration of juvenileadult pairs observed in this study showed many similarities with previous studies. Juvenile-adult pairs generally do not remain near natal colonies to feed in local feeding areas, but instead move rapidly away from the colony (Olsson et al. 1999, Falk et al. 2001, Camphuysen 2002, this study). Pairs departing the colony tend to move in similar directions but eventually become highly dispersed over vast regions (Hatch et al. 2000, Camphuysen 2002, this study). Higher densities of pairs eventually accumulate in certain areas, that have been described as nursery areas (Hatch et al. 2000, Camphuysen 2002, this study). Generally, single pairs are observed during the dispersal period (e.g. Hope Jones \& Rees 1985) but flock sizes increase within nursery areas (Camphuysen 2002, this study). Characteristics of nursery areas that appear to result in the concentration of juvenile-adult pairs include higher prey density (this study) and/or lower densities of avian predators that target juvenile murres (Camphuysen 2002, this study).

\section{Summary}

As found in previous studies (Schneider \& Piatt 1986, Heinemann et al. 1989, Mehlum et al. 1996, Logerwell et al. 1998, Fauchald et al. 2000), the scales at which seabirds tracked their prey were variable (range: 0.2 to $17.3 \mathrm{~km}$ ) and only approximately $30 \%$ of the segments analyzed showed significant clustering of murres at prey aggregations. This shows that there was much variability in individual-level behavioural interactions between predators and prey. Individual behaviour, however, was integrated at the population level in 2 ways. First, different dispersal capabilities and physiological requirements of flightless murres compared to those that can fly resulted in consistently larger tracking scales of prey. These results have important implications for the scale of study during different periods of the annual cycle of a predator, when various constraints and dietary considerations can interact to produce variation in behavioural responses to prey distribution and densities (Ives et al. 1993). Second, on the larger scale of post-breeding migration, individuals accumulated in an area of high prey density, or nursery area. Flightless adult and juvenile murres are highly vulnerable to human activities (e.g. oil pollution, fishing; Olsson et al. 1999) due to their reduced abilities to disperse away from an area. Identifying such key habitats is important when considering protected areas in marine ecosystems.

Acknowledgements. We thank Fran Mowbray and Richard O'Driscoll for providing the integrated capelin acoustic data for all surveys and also to Richard for providing Matlab ${ }^{\odot}$ routines. Special thanks to the crew of the Canadian Coast Guard RV 'Teleost', Larry Easton (Easton family), Dave Sencial and Becky Sjare for providing logistical support, equipment and software. We also thank David Fifield and Gail Fraser for help with data collection. Patricia Healy also described in detail the standard methods used to prepare fish tissue and feather samples for stable isotope analysis. We are grateful to David Schneider for his time and effort in reviewing earlier drafts of this manuscript. Funding was provided by NSERC postgraduate scholarship to G.K.D., NSERC Operating Grant to W.A.M., Mountain Equipment Co-op, Royal Bank Marine Studies Fund, The National Chapter of Canada IODE, Orville Erickson Memorial Fund and Canadian Federation of University Women.

\section{LITERATURE CITED}

Abrahams MV (1989) Foraging guppies and the ideal free distribution: the influence of information on patch choice. Ethology 82:116-126 
Adams PA, Robertson GJ, Jones IL (2000) Time-activity budgets of harlequin ducks molting in the Gannet Islands, Labrador. Condor 102:703-708

Ainley DG, Spear LB, Allen SG, Ribic CA (1996) Temporal and spatial patterns in the diet of the common murre in California waters. Condor 98:691-705

Birkhead TR (1974) Movement and mortality rates of British Guillemots. Bird Study 21:241-254

Birkhead TR, Taylor AM (1977) Moult of the guillemot Uria aalge. Ibis 119:80-85

Bradstreet MSW, Brown RGB (1985) Feeding ecology of the Atlantic Alcidae. In: Nettleship DN, Birkhead TR (eds) The Atlantic Alcidae. Academic Press, Toronto, p 264-318

Brown RGB (1986) Revised atlas of eastern Canadian seabirds. Ministry of Supply and Services Canada, Ottawa

Bryant R, Jones IL, Hipfner JM (1999) Responses to changes in prey availability by common murres and thick-billed murres at the Gannet Islands, Labrador. Can J Zool 77:1278-1287

Burger AE, Piatt JF (1990) Flexible time budgets in breeding common murres: buffers against variable prey abundance. Stud Avian Biol 14:71-83

Cairns DK, Schneider DC (1990) Hot spots in cold water: feeding habitat selection by thick-billed murres. Stud Avian Biol 14:52-60

Cairns DK, Montevecchi WA, Threlfall W (1989) Researcher's guide to Newfoundland seabird colonies. Memorial Univ Nfld Occas Pap Biol 14:1-34

Camphuysen CJ (2002) Post-fledging dispersal of common guillemots Uria aalge guarding chicks in the North Sea: the effect of predator presence and prey availability at sea. Ardea 90:103-119

Camphuysen CJ, Webb A (1999) Multi-species feeding associations in North Sea seabirds: jointly exploiting a patchy environment. Ardea 87:177-198

Carscadden JE, Nakashima BS (1997) Abundance and changes in distribution, biology and behavior of capelin in response to cooler waters of the 1990s. In: Forage fishes in marine ecosystems. Proc Int Symp Rose of Forage Fishes in Alaska. Sea Grant Program Report No. 97-01, Fairbanks, AL, p 457-468

Carscadden JE, Frank KT, Miller DS (1989) Capelin (Mallotus villosus) spawning on the southeast shoal: influence of physical factors past and present. Can J Fish Aquat Sci 45:1743-1754

Carscadden JE, Nakashima BS, Frank KT (1997) Effects of fish length and temperature on the timing of peak spawning in capelin (Mallotus villosus). Can J Fish Aquat Sci 54:781-787

Carscadden JE, Montevecchi WA, Davoren GK, Nakashima BS (2002) Trophic relationships among capelin (Mallotus villosus) and marine birds in a changing ecosystem. ICES J Mar Sci 59:1027-1033

Colbourne E, de Young B, Narayanan S, Helbig J (1997) Comparison of hydrography and circulation on the Newfoundland shelf during 1990-1993 with the long-term mean. Can J Fish Aquat Sci 54(Suppl 1):68-80

Coyle KO, Hunt GL Jr, Decker MB, Weingartner TJ (1992) Murre foraging, epibenthic sound scattering and tidal advection over a shoal near St George's Island. Mar Ecol Prog Ser 83:1-14

Croll DA, McLauren EB (1993) Diving metabolism and thermoregulation in common and thick-billed murres. J Comp Physiol 163:160-166

Croll DA, Gaston AJ, Burger AE, Konnoff D (1992) Foraging behavior and physiological adaptation for diving in thickbilled murres. Ecology 73:344-356
Davoren GK (2000) Variability in foraging in response to changing prey distributions in rhinoceros auklets. Mar Ecol Prog Ser 198:283-291

Davoren GK (2001) Predator-prey interactions of common murres (Uria aalge) and fish in the northwest Atlantic: foraging strategies on multiple scales. PhD thesis, Memorial University of Newfoundland, St. John's

Davoren GK, Montevecchi WA (2003) Consequences of foraging trip duration on provisioning behaviour and fledging condition of common murres. J Avian Biol 34 (in press)

Decker MB, Hunt GL Jr (1996) Foraging by murres (Uria spp.) at tidal fronts surrounding the Pribilof Islands, Alaska, USA. Mar Ecol Prog Ser 139:1-10

de Vries J, van Eerden MR (1995) Thermal conductance in aquatic birds in relation to the degree of water contact, body mass, and body fat: energetic implications of living in a strong cooling environment. Physiol Zool 68: 1143-1163

Diamond AW, Gaston AJ, Brown RGB (1993) A model of the energy demands of seabirds of eastern and Arctic Canada. In: Montevecchi WA (ed) Studies of high-latitude seabirds, No 77. Canadian Wildlife Service Occasional Paper, Ottawa, p 1-35

Elliot RD, Ryan PC, Lidster WW (1990) The winter diet of thick-billed murres in coastal Newfoundland waters. Stud Avian Biol 14:125-138

Falk K, Dall'Antonia L, Benvenuti S (2001) Mapping preand post-fledging foraging locations of thick-billed murres in the North Water polynya. Ecography 24:625-632

Fauchald P, Erikstad KE (2002) Scale-dependent predatorprey interactions: the aggregative response of seabirds to prey under variable prey abundance and patchiness. Mar Ecol Prog Ser 231:279-291

Fauchald P, Erikstad KE, Skarsfjord H (2000) Scale-dependent predator-prey interactions: the hierarchical spatial distribution of seabirds and prey. Ecology 81:773-783

Flint PL, Fowler AC (1998) A drift experiment to assess the influence of wind on recovery of oiled seabirds on St Paul Island, Alaska. Mar Pollut Bull 36:165-166

Fretwell SD, Lucas JH Jr (1970) On territorial behaviour and other factors influencing habitat distribution in birds. Acta Biotheor 19:16-36

Gabrielsen GW (1994) Energy expenditure in Arctic seabirds. PhD thesis, University of Tromso

Gaston AJ, Jones IL (1998) The Auks. Oxford University Press, New York

Gaston AJ, Nettleship DN (1981) The thick-billed murres of Prince Leopold Island: a study of the breeding ecology of a colonial High Arctic seabird. Can Wildl Serv Monogr Ser 6, Ottawa

Grunbaum D (1998) Using spatially explicit models to characterize foraging performance in heterogeneous landscapes. Am Nat 151:97-115

Haney JC, Solow AR (1992) Analyzing quantitative relationships between seabirds and marine resource patches. Curr Ornithol 9:105-160

Hassel M (1966) Evaluation of parasite or predator responses. J Anim Ecol 35:65-75

Hatch SA, Meyers PM, Mulcahy DM, Douglas DC (2000) Seasonal movements and pelagic habitat use of murres and puffins determined by satellite telemetry. Condor 102: 145-154

Haury LR, McGowan JA, Wiebe PH (1978) Patterns and processes in the time-space scales of plankton distributions In: Steele JH (ed) Spatial pattern in plankton communities. Plenum Press, New York, p 277-327 
Heinemann D (1981) A rangefinder for pelagic bird censusing. J Wildl Manage 45:489-493

Heinemann D, Hunt GL Jr, Everson I (1989) Relationships between the distributions of marine avian predators and their prey, Euphausia superba, in Bransfield Strait and southern Drake Passage, Antarctica. Mar Ecol Prog Ser 58:3-16

Hobson KA (1993) Trophic relationships among High Arctic seabirds: insights from tissue-dependent stable-isotope models. Mar Ecol Prog Ser 95:7-18

Hobson KA, Montevecchi WA (1991) Stable isotopic determinations of trophic relationships of great auks. Oecologia 87:528-531

Hobson KA, Piatt JF, Pitocchelli J (1994) Using stable isotopes to determine seabird trophic relationships. J Anim Ecol 63:786-798

Holdgate MW (1971) The seabird wreck in the Irish Sea autumn 1969. Natural Environment Research Council, London

Holling CS (1966) The functional response of invertebrate predators to prey density. Mem Entomol Soc Can 48:1-86

Hope Jones P, Rees EIS (1985) Appearance and behaviour of immature guillemots and razorbills at sea. $\mathrm{Br}$ Birds 78:370-377

Horne JK, Schneider DC (1994) Lack of spatial coherence of predators and prey: a bioenergetic explanation for Atlantic cod feeding on capelin. J Fish Biol 45(Suppl A):191-207

Hunt GL Jr, Harrison NM (1990) Foraging habitat and prey taken by least auklets at King Island, Alaska. Mar Ecol Prog Ser 65:141-150

Irons DB (1998) Foraging area fidelity of individual seabirds in relation to tidal cycles and flock feeding. Ecology 79:647-655

Ives AR, Kareiva P, Perry R (1993) Response of a predator to variation in prey density at three hierarchical scales: lady beetles feeding on aphids. Ecology 74:1929-1938

Jarman WM, Hobson KA, Sydeman WJ, Bacon CE, McLaren EB (1996) Influence of trophic position and feeding location on contaminant levels in the Gulf of the Farallones food web revealed by stable isotope analysis. Environ Sci Technol 30:654-660

Logerwell EA, Hewitt RP, Demer DA (1998) Scale-dependent spatial variance patterns and correlations of seabirds and prey in the southeastern Bering Sea as revealed by spectral analysis. Ecography 21:212-223

MacLennan DN, Fernandes PG, Dalen J (2002) A consistent approach to definitions and symbols in fisheries acoustics. ICES J Mar Sci 59:365-369

Mehlum F, Hunt GL Jr, Klusek Z, Decker MB, Nordlund N (1996) The importance of prey aggregations to the distribution of Brunnich's guillemots in Storfjorden, Svalbard. Polar Biol 16:537-547

Mizutani H, Fukuda M, Kabaya Y (1992) ${ }^{13} \mathrm{C}$ and ${ }^{15} \mathrm{~N}$ enrichment factors of feathers of 11 species of adult birds. Ecology 73:1391-1395

Monaghan P, Walton P, Wanless S, Uttley JD, Burns MD (1994) Effects of prey abundance on the foraging behaviour, diving efficiency and time allocation of breeding guillemots Uria aalge. Ibis 136:214-222

Montevecchi WA, Kirch DA (1996) Great Auk Pinguinus impennis. In: Poole A, Gill F (eds) The birds of North America (no. 260). Academy of Natural Sciences, Philadelphia, PA and American Ornithologists' Union, Washington, DC, p 1-20

Montevecchi WA, Tuck LM (1987) Newfoundland birds: exploitation, study, conservation. Nuttall Ornithological Club, Cambridge, MA
Murphy ME, King JR (1992) Energy and nutrient use during moult by white-crowned sparrows Zonotrichia leucophrys gambelii. Ornis Scand 23:304-313

Nakashima BS (1992) Patterns in coastal migration and stock structure of capelin (Mallotus villosus). Can J Fish Aquat Sci 49:2423-2429

O'Driscoll RL (1998) Description of spatial pattern in seabird distributions along line transects using neighbour K statistics. Mar Ecol Prog Ser 165:81-94

O'Driscoll RL, Rose GA (1999) Seasonal changes in abundance, distribution and vertical migration of capelin in Placentia Bay. In: Anonymous (ed) Capelin in SA2 + Div 3KL. Canadian Stock Assessment Research Document, 99/206, p 182-195

O'Driscoll RL, Schneider DC, Rose GA, Lilly GR (2000) Potential contact statistics for measuring scale-dependent spatial pattern and association:an example of northern cod (Gadus morhua) and capelin (Mallotus villosus). Can J Fish Aquat Sci 57:1355-1368

O'Driscoll RL, Anderson JT, Mowbray F (2001) Abundance and distribution of capelin from an acoustic survey in conjunction with the 1999 Pelagic Juvenile Fish Survey. In: Anonymous (ed) Capelin in SA2 + Div 3KL. Canadian Stock Assessment Research Document, 2001/161, p 120-150

Olsson O, Fransson T, Larsson K (1999) Post-fledging migration of common murres Uria aalge in the Baltic Sea: management implications. Ecography 22:233-239

Orians GH, Pearson NE (1979) On the theory of central place foraging. In: Horn DJ, Mitchell RD, Stairs GR (eds) Analyses of ecological systems. Ohio State University Press, Columbus, p 154-177

Ostrand WD, Coyle KO, Drew GS (1998) Selection of foraging-fish schools by murrelets and tufted puffins in Prince William Sound, Alaska. Condor 100:286-297

Payne RB (1972) Mechanisms and control of molt. In: Farner DS, King JR, Parkes KC (eds) Avian biology, Vol 2. Academic Press, Toronto, p 103-155

Petrie B, Anderson C (1983) Circulation on the Newfoundland continental shelf. Atmos Ocean 21:207-226

Piatt JF (1987) Behavioural ecology of common murre and Atlantic puffin predation on capelin: implications for population biology. $\mathrm{PhD}$ thesis, Memorial University of Newfoundland, St. John's

Piatt JF (1990) The aggregative response of common murres and Atlantic puffins to schools of capelin. Stud Avian Biol 14:36-51

Piatt JF, Nettleship DN (1985) Diving depths of four alcids. Auk 102:293-297

Regehr HM, Montevecchi WA (1997) Interactive effects of food shortage and predation on breeding failure of blacklegged kittiwakes: indirect effects of fisheries activities and implications for indicator species. Mar Ecol Prog Ser 155:249-260

Rose GA, Leggett WC (1990) The importance of scale to predator-prey spatial correlations: an example of Atlantic fishes. Ecology 71:33-43

Rowe S, Jones IL, Chardine JW, Elliot RD, Veitch BG (2000) Recent changes in the winter diet of murres (Uria spp.) in coastal Newfoundland waters. Can J Zool 78:495-500

Russell RW, Hunt GL Jr, Coyle KO, Cooney RT (1992) Foraging in a fractal environment: spatial patterns in a marine predator-prey system. Landsc Ecol 7:195-209

Schneider DC (1991) The role of fluid dynamics in the ecology of marine birds. Oceanogr Mar Biol 29:487-521

Schneider DC, Piatt JF (1986) Scale-dependent correlation of seabirds with schooling fish in a coastal ecosystem. Mar Ecol Prog Ser 32:237-246 
Shackell NL, Carscadden JE, Miller D (1994) Diel vertical migration of capelin (Mallotus villosus) and its effect on acoustic estimates of density. In: ICES Council Meeting Pap 1994:5-18

Sih A (1984) The behavioral response race between predator and prey. Am Nat 123:143-150

Solomon ME (1949) The natural control of animal populations. J Anim Ecol 18:1-35

Spear LB (1993) Dynamics and effect of western gulls feeding in a colony of guillemots and Brandt's cormorants. J Anim Ecol 62:399-414

Sydeman WJ, Hobson KA, Pyle P, McLaren EB (1997) Trophic relationships among seabirds in central California: combined stable isotope and conventional dietary approach. Condor 99:327-336

Tasker ML, Hope Jones P, Dixon T, Blake BF (1984) Counting seabirds at sea from ships: a review of methods employed and a suggestion for a standardized approach. Auk 101: 567-577

Thompson CW, Wislon ML, Melvin EF, Pierce DJ (1998) An unusual sequence of flight-feather molt in common murres and its evolutionary implications. Auk 115:653-669

Thompson DR, Furness RW (1995) Stable-isotope ratios of carbon and nitrogen in feathers indicate seasonal dietary

Editorial responsibility: Otto Kinne (Editor),

Oldendorf/Luhe, Germany shifts in northern fulmars. Auk 112:493-498

Thompson DR, Lilliendahl K, Solmundsson J, Furness RW, Waldron S, Phillips RA (1999) Trophic relationships among six species of Icelandic seabirds as determined through stable isotope analysis. Condor 101:898-903

Tregenza T (1995) Building on the ideal free distribution. Adv Ecol Res 26:253-307

Tuck LM (1961) The murres. Can Wildl Serv Monogr Ser No. 1, Ottawa

Varoujean DH, Sanders SD, Graybill MR, Spear LB (1979) Aspects of common murre breeding biology. Pac Seabird Group Bull 6:28

Vilhjalmsson H (1994) The Icelandic capelin stock. Rit Fiskideildar 8:1-213

Walsh C (2001) Copulation behaviour, paternity and genetic relatedness in the common murre, Uria aalge. PhD thesis, Memorial University of Newfoundland, St. John's

Wanless S, Harris MP (1986) Time spent at the colony by male and female guillemots Uria aalge and razorbills Alca torda. Bird Study 33:168-176

Wittenberger JF, Hunt GL Jr (1985) The adaptive significance of coloniality in birds. In: Famer DS, King JR, Parkes KC (eds) Avian Biology, Vol 8. Academic Press, Toronto, p $1-77$

Submitted: February 28, 2002; Accepted: August 19, 2002 Proofs received from author(s): December 2, 2002 